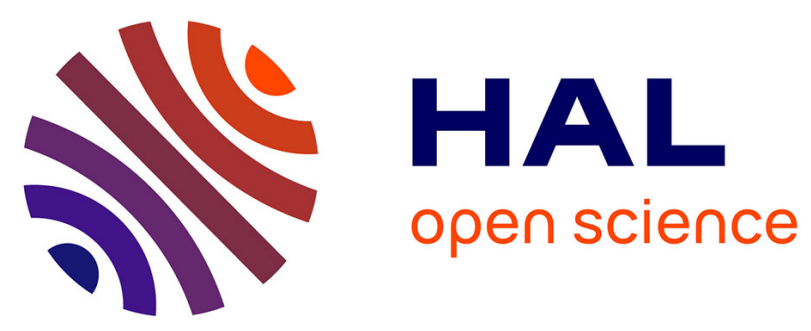

\title{
Ultimate time pressure: Conceptualisation and measurement
}

\author{
Andréa Gourmelen, Bertrand Urien, Marine Le Gall-Ely
}

\section{To cite this version:}

Andréa Gourmelen, Bertrand Urien, Marine Le Gall-Ely. Ultimate time pressure: Conceptualisation and measurement. Recherche et Applications en Marketing (English Edition), 2016, 31 (4), pp.5 - 27. $10.1177 / 2051570716658466$. hal-01904355

\section{HAL Id: hal-01904355 \\ https://hal.umontpellier.fr/hal-01904355}

Submitted on 2 Mar 2021

HAL is a multi-disciplinary open access archive for the deposit and dissemination of scientific research documents, whether they are published or not. The documents may come from teaching and research institutions in France or abroad, or from public or private research centers.
L'archive ouverte pluridisciplinaire $\mathbf{H A L}$, est destinée au dépôt et à la diffusion de documents scientifiques de niveau recherche, publiés ou non, émanant des établissements d'enseignement et de recherche français ou étrangers, des laboratoires publics ou privés. 


\title{
Ultimate time pressure: conceptualization and measurement
}

\author{
Andréa Gourmelen * \\ Université Montpellier, Montpellier Recherche en Management (MRM - EA 4557), \\ France
}

\section{Bertrand Urien}

Université Bretagne Occidentale, Information, Coordination, Incitations (ICI - EA 2652), France

Marine Le Gall-Ely

Université Bretagne Occidentale, Information, Coordination, Incitations (ICI - EA 2652), France

* Corresponding author:

Andréa Gourmelen, Université Montpellier, IUT Montpellier-Sète - Département Techniques de Commercialisation, 99 Avenue d'Occitanie, 34296 Montpellier Cedex 5. Email: andrea.gourmelen@univ-montp2.fr 


\title{
Le concept de pression temporelle ultime et sa mesure
}

\section{Résumé :}

Cette recherche définit la pression temporelle ultime (PTU) comme la conscience d'un temps restant à vivre limité par le rapprochement de la mort et les réactions affectives qui l'accompagnent. Il s'agit d'une nouvelle catégorie de pression temporelle se différenciant des pressions temporelles chronique (PTC) ou situationnelle (PTS). Une échelle de mesure en est proposée dont la validité nomologique est testée sur différentes motivations au bénévolat des retraités, permettant notamment d'aller au-delà de l'utilisation du temps disponible de cette population, comme critère primordial de recrutement et fidélisation de bénévoles.

Mots-clés : bénévolat, échelle de mesure, pression temporelle ultime, retraités, vieillissement.

\section{Ultimate time pressure: conceptualization and measurement}

\begin{abstract}
:
This research defines ultimate time pressure (UTP) as the consciousness of a limited time remaining to live (due to proximity of death) and related feelings. UTP is a new type of time pressure, which differs from chronic time pressure (CTP) and situational time pressure (STP). The objective is to construct a measurement scale, the nomological validity of which will then be used to test the impact of UTP on retirees' motivations to volunteer. Quantifying this influence is important because it will enable us to move away from using "free time" as the main criteria in the recruitment and retention of volunteers from this target population.
\end{abstract}

Key-words: volunteerism, measurement scale, ultimate time pressure, retirees, ageing. 


\section{INTRODUCTION}

'Those months which we have left to live are more important than all the years lived before, and we must live them well' (Tolstoï, 'Je m'en vais', Lettres II, 1986: 386).

Although entering retirement is not necessarily experienced as a turning point in life (Lalive d'Epinay and Cavalli, 2007), it is still believed to be a catalyst for becoming conscious of the ageing process (Attias-Donfut, 2006; Guiot, 2006). Individuals gradually begin to contemplate their own demise (Szmigin et Carrigan, 2001; Urien, 2007), and may even start to reason from an altered time perspective, that is, they may think of life in terms of time left to live, and no longer time since birth (Caradec, 2008).

Certain studies in marketing have investigated the impact of the perception of one's own death on consumer behaviour. Some of these studies have focussed on the cognitive aspects linked to the approach of death (Malas and Guiot, 2008; Malas and Safraou, 2008), but have paid little attention to the feelings individuals experience. Other research has tackled affects linked to the idea of death (Urien, 2002, 2003), but does not address perceived proximity of death. These analyses raise questions relating to the perception of time left to live in retired older people, who must confront the notion that their time is limited by the approach of their own demise. To what extent are they conscious of death drawing near? Do they experience only negative affective reactions faced with its approach? Do the cognitive and affective aspects influence their behaviour differently? This article aims to set out the concept of 'ultimate time pressure' (UTP), integrating both the cognitive and affective aspects linked to our limited time left in life.

In the first part, a literature review on ageing and the generic concept of time pressure allows us to address the concept of ultimate time pressure. This is followed by a qualitative study (part 2), which permits an in-depth examination of the structure of UTP in order to propose a measurement scale (part 3). Lastly, the nomological validity and the practical scope of this concept will be addressed by analysing the impact of UTP on retirees' motivations to volunteer. In this research, the term 'volunteering' refers to 'formal' volunteering within an organisation (Erlinghagen, 2010), generally a charity (Prouteau and Wolff, 2004).

\section{ULTIMATE TIME PRESSURE: THEORETICAL FOUNDATIONS AND} CONCEPTUALISATION 
Perception of time left to live and perception of death in old age were initially studied in psychoanalysis and clinical psychology in relation to ageing, before they appeared in the field of marketing research. These source disciplines highlight the generic events that punctuate old age, retirement in particular, and lead to the gradual realisation that death is approaching. (1) Differential psychology, which focusses on interindividual differences and their measurement (Huteau, 2006), permits the study of the various defence mechanisms that allow individuals to confront this ageing-related reduction in time left to live. (2) While the literature focusses on the cognitive aspects of time left to live, the existence of defence mechanisms leads to the conclusion that death drawing near may have an emotional impact on retirees. For this reason, this research is interested in the affective reactions associated with realising that death is approaching. (3) Retirees, torn between regrets linked to lost time, fear of running out of time before death and a desire to make the most of their time remaining, seem to be under significant pressure linked to their time left to live: ultimate time pressure.

\section{The ageing process: psychoanalytical and psychological origins}

Firstly, the Freudian approach does not consider ageing to be a phenomenon capable of provoking specific behavioural responses in older people. In fact, this approach generally tends to link behaviour to the infantile phase (Gagey, 1989). However, despite the importance of childhood in the organisation of the psyche, individuals can evolve as they age. They are therefore affected by 'the intimate challenge of personally confronting time' (Bianchi, 1989: 2) that results from ageing. In addition, in developmental psychology, scholars state that one's personality develops throughout life. According to Erikson (1959), at each stage in life, the challenge is to find a balance between (positive and negative) extremes. For example, concerning end of life, the goal is to quietly fall into the generational cycle. To do so, individuals must resolve an internal conflict between two extremes: generativity and stagnation. Generativity, the positive extreme, comes from the desire for symbolic immortality and being useful to others. Therefore, generativity is at once a narcissistic gesture, involving creating something in one's own image, and an altruistic action, such as nurturing the next generation (McAdams et al., 1993). In contrast, the negative extreme, called stagnation, is a 'lethargic attitude to the world' (Van Hiel et al., 2006: 545). In other words, this life stage pits individuals' ability to preserve and guide the next generation (generativity) against the impression of having nothing to offer these future generations (stagnation). Once this internal conflict is resolved, a new one emerges: the conflict between 'personal integrity' and 
'despondency'. The goal is to succeed in understanding one's life in order to accept one's death. Ageing is thus understood as a process that causes successive identity crises. During this period, individuals break away from 'narcissistic' objects, that is, objects that make up their identity (Bianchi, 1989). They have to mourn their professional life upon retirement (Gagey, 1989; Talpin, 2013) and mourn their former image following the physical changes linked to old age (Balbo, 1989). Some authors refer to mourning life itself (Bianchi, 1989), or even mourning oneself by accepting the losses to come (Thomas, 1989). In this way, after entering retirement, free time can become 'empty' time (Talpin, 2013: 58). This means unfilled time that is perfect for introspection, a time to reflect on the meaning of one's life, notably when the individual perceived work as being indispensable to their wellbeing (Marbot and Peretti, 2004). The consciousness of approaching death, gradually developed in such a way (Caradec, 2008; Misrahi, 2006), results in the emergence of conscious and/or unconscious defence mechanisms (Ionescu et al., 2012). The latter are highlighted by supporters of socioemotional selectivity theory (Carstensen, 1991; Reed and Carstensen, 2012), and terror management theory (TMT - Pyszczynski, Greenberg and Solomon, 1999). TMT states that all individuals who are conscious of death (confronted with something that reminds them of the fragility of their existence), seek to conform to the values promoted by their culture, an entity that will outlive them. On the other hand, socioemotional selectivity theory suggests that the approach of death has an effect on how information is processed by older people. In old age, individuals prefer to seek out emotions over seeking out information. Moreover, they tend to pay more attention to, and better remember, information that creates a positive emotional reaction (in comparison to negative stimuli). However, why does this phenomenon, called the 'positivity effect' (Reed and Carstensen, 2012), emerge in individuals conscious of their limited time left to live? Is it because death is associated with unpleasant affects (Bianchi, 1987) and individuals approaching it would prefer to reduce the negative affects they experience? These questions are yet to be answered and allow us to break down the perception of time left to live into its cognitive and affective components.

\section{The perception of time left to live: cognitive and affective aspects}

In marketing, Bergadaà (1988, 1989) distinguishes between time as a 'resource' and time 'perspective'. Time as a 'resource' corresponds to the amount of time an individual allocates to an activity. Time 'perspective' is subjective and refers to individual perception (e.g.: developing and planning future goals, preference for a time period, length of time horizon, 
etc.). The perception of time left to live is part of this time perspective, insofar as it questions how extended and open our time horizon is. Do any constructs related to the perception of time left to live exist? Can they be operationalised?

Time horizon: a cognitive variable demonstrating the perceived proximity of death The premise of a cognitive dimension related to the perception of time left to live appears in research in psychoanalysis and psychology on older people's perception of death. According to Gagey (1989: 7), the conscious swings from moriendus (I will die one day) to morturus (I will die soon). 'Midlife' seems to be the time best suited to this realisation (Bianchi, 1987; Fromage, 2007). Carstensen (1991) explores this idea in depth with socioemotional selectivity theory. This theory underlines the interindividual cognitive differences relating to time left to live. Individuals are conscious, to differing extents, that death is drawing near. This level of consciousness varies over time and can impact older people's social connections. The 'time horizon' variable, supposed to reflect the level of consciousness of the approach of death, has since attracted interest in marketing research (Bourcier-Béquaert and De Barnier, 2011; Guiot, 2006). More specifically, time horizons are said to be 'limited' for those that think their end is near (as opposed to the so-called 'open' time horizon of individuals who think they have plenty of time ahead of them). The cognitive aspect of the perception of time left to live can thus be understood in part by the time horizon scale (Carstensen and Lang, 1996). However, issues of content validity have arisen concerning this scale (Malas and Safraou, 2008). In fact, certain items cover aspects related to hope for the future and future projects, which go beyond the concept it was designed to measure. By definition, a time horizon must only measure the perceived proximity of death and not the way in which individuals hope to use their time remaining.

\section{The existence of affective aspects associated with the perceived proximity of death}

Is the perception of time left to live only cognitive? Some elements evoked in the literature call this idea into question. Indeed, the cognitive rather than affective aspects are the principal point of discussion. The latter instead appear in the form of assessments, made by certain researchers, that suggest the approach of death does not leave retirees emotionally unaffected. Bianchi (1987) states that death is generally associated with unpleasant affects. More specifically, the literature on consumer behaviour focusses on the affects related to thinking about one's own death. In this way, death anxiety is defined as a range of negative affective reactions that are likely develop in individuals faced with the idea of their own demise (Urien, 
2002, 2003). Although this work does not address time horizons specifically, it nonetheless highlights the existence of the negative affective reactions that occur when imagining one's own death. These ideas lead to the conclusion that negative affective reactions can be associated with the cognitive aspects of the perception of time left to live. On this topic, Vergely (2010: 108) speaks of 'the hardship of time', stating that the perception of time left to live can exhaust individuals and cause them suffering. Indeed, regret or sadness can appear: time left to live is less worthwhile than time lived in previous life stages, during which individuals would have worked, had fewer health problems, and so on (Clément, 2007). Nonetheless, other than a fear of dying in the strict sense of the term, some older people are afraid of not having enough time to accomplish everything they would like to accomplish before dying (De Hennezel, 2010). A consciousness that death is near therefore provokes the desire to 'make the most of your lifetime [...] before death puts a definitive end to it' (Rosa, 2010: 223). As a counterpoint to this work, other researchers underline the positive affective reactions associated with a consciousness of approaching death and consequently of the limited time left to live. Wiedmer (2010) highlights the importance attached to the desire to take advantage of every moment, which therefore makes every moment precious. Therefore, retired older people pay more attention than others to how they use their remaining time (Szmigin and Carrigan, 2001; Warburton and Crosier, 2001). They want to take advantage of the remainder of their lives, while bearing in mind that they will not 'last forever' (Marchand, Quéniart and Charpentier, 2010: 67). Consequently, a consciousness of one's limited time left to live can be accompanied by a desire to make the most of it, to feel alive. These affective elements mentioned in the literature demonstrate that the level of consciousness of the approach of death can certainly be higher or lower in two individuals of the same age. It also shows, however, that positive and/or negative affective reactions seem to be associated with this level of consciousness.

\section{Integrating elements with the concept of ultimate time pressure}

Although the cognitive and affective elements related to the approach of death are addressed in the literature, to our knowledge, no existing concept integrates these different aspects. We propose introducing a new concept, ultimate time pressure (UTP), taking into account such cognitive and affective elements. After defining this new concept below, it will be positioned in relation to other types of time pressure. 


\section{Ultimate time pressure: a cognitive-affective concept}

Bourcier-Béquaert and De Barnier (2012) associate time pressure with the consciousness of a limited time horizon in older people. According to the literature, a time horizon limited by death as the ultimate time limit seems to be associated with affective reactions. Such reactions are positive when individuals want to make the most of their time left. On the other hand, they are negative when individuals have regrets or fear not having enough time remaining before death. This demonstrates the existence of a specific kind of time pressure, linked to time left to live. Indeed, according to the literature, there are different categories of time pressure. Nonetheless, all kinds of time pressure are defined as the combination of two elements: the consciousness of a time constraint and the feelings that accompany such consciousness (Lallement, 2010; Szollos, 2009). These two elements are found in the perception of time left to live, hence the term ultimate time pressure.

Ultimate Time Pressure can thus be defined as the realisation that one's time left to live is limited by the approach of death (cognitive aspect of UTP), and the affective reactions that accompany this realisation (affective aspect of UTP).

UTP is therefore a specific type of time pressure. It is examined in more depth below by comparing it to other types of time pressure.

\section{Ultimate time pressure, a hybrid time pressure}

Marketing research related to time pressure is distinct from the literature related to ageing and consequently does not address the approach of death. Two types of time pressure are usually identified (Lallement, 2010; Lallement and Machat, 2011): 'situational time pressure' (STP) and 'chronic time pressure' (CTP). STP is 'the individual assessment of occasionally not having enough time to complete a task' (Lallement, 2010: 48). It is therefore short-term and comes to a close when the time limit in question passes, such as the end of a product offer, or the date of an event, for example.

In contrast, a 'chronic, incessant battle to achieve ever-more things in ever-less time' (Rizkalla, 1989: 180) can be a continual, daily occurrence for some individuals. No time limit creates this time pressure and, as a result, it never stops. The term 'CTP' has gradually come to identify the consciousness of a permanent lack of time and the accompanying feelings (Lallement and Machat, 2011; Szollos, 2009). These feelings are negative (panic, sadness) when individuals believe they are subjected to a time constraint. In contrast, they experience 
positive feelings when they feel stimulated by this permanent lack of time (Lallement and Machat, 2011; Machat and Lallement, 2011).

By definition, ultimate time pressure has certain characteristics in common with other types of time pressure: its long-term nature (until death) makes it similar to CTP, and the presence of a time limit (the moment of death) makes it similar to STP. It is a hybrid: not fully chronic, nor fully situational. This allows it to be positioned as a third time pressure category based on its distinct characteristics (see table 1).

\section{< Insert table 1 - Distinctive characteristics of types of time pressure >}

In summary, the literature related to ageing highlights the existence of cognitive and affective elements related to the perception of time left to live. As a result, it is necessary to go beyond the time horizon concept, which addresses the cognitive aspects related to the approach of death. Discussing UTP allows us to cover both aspects, as all types of time pressure are generally defined by a combination of cognitive and affective aspects related to a time constraint. Examining the literature on time pressure in depth therefore allows ultimate time pressure to be understood as its own separate time pressure category. Consequently, UTP is a cognitive-affective concept, but its structure remains unclear. Are the affective reactions exclusively positive or negative (individuals experiencing either one or the other of these affective categories), such as in the case of CTP (Machat and Lallement, 2011)? In contrast, can individuals be psychologically ambivalent to their time left to live (individuals simultaneously experiencing both positive and negative affects)? Which affects are involved? A qualitative study is necessary to clarify the structure of UTP and to anticipate the creation of a measurement scale.

\section{AN IN-DEPTH STUDY OF THE CONCEPT OF ULTIMATE TIME PRESSURE, A QUALITATIVE APPROACH}

\section{Methodology}

A qualitative study was carried out (18 semi-structured face-to-face interviews, averaging 55 minutes in duration with retirees aged between 60 and 86 years old) to supplement the literature review and define the dimensions of UTP. Questions related to time left to live were added to an interview guide that also addressed volunteering. This topic made participants feel more at ease and allowed for an in-depth study of UTP and motivations. To avoid any hesitation on the part of participants, the sentences related to time left to live were presented 
as quotations or the remarks of other retirees, resembling a 'third person' projective test. The transcribed interviews were summarised, subject to cross-case analysis (Huberman and Miles, 1991) and lastly content thematic analysis (Jolibert and Jourdan, 2011a). Codes were developed inductively and deductively. This was based on the interview guide while allowing the development of new categories from the results (Allard-Poesi, 2003). In addition, the meaning unit (the smallest unit that carries meaning) was chosen as the coding unit (Point and Voynnet-Fourboul, 2006). For example, when a retiree mentioned the same theme in one paragraph three times, three verbatim quotations were noted down. Coding was conducted with Nvivo 10 software to make use of the 'word frequency' function facilitating item generation (Bazeley, 2007). In the interest of limiting bias, the study was evaluated according to Miles and Huberman's quality criteria (2003).

\section{Results of the qualitative study}

The interview analysis shows that ultimate time pressure does not manifest itself in the same way for all retirees. Individual differences in terms of presence and intensity of UTP were observed for both cognitive and affective aspects.

The cognitive dimension of UTP

The consciousness of the approach of death is expressed in three different ways (delicately, indirectly, frankly). Firstly, it was difficult for some individuals to go beyond platitudes about how short life is, in all likelihood due to the fact that death is a taboo subject (10 individuals, 16 quotations). In addition, certain participants spoke about the matter indirectly, via the deaths of others that they had witnessed and that reminded them of the final time limit (9 individuals, 16 quotations): 'You're more aware that... Obviously you think about death, yes. Of course because, you've got friends that die, with tumours, and all that, cancer, that they shouldn't have had' (Susanne, 65 years old). Certain participants discussed the topic more easily and spoke frankly about their own death, either initially or after having started with the sentences above (9 individuals, 25 quotations): 'I think I'll get to the end of my life in any case. Even if I live another, say, 5, 10 years, I don't know' (Jean, 75 years old). 'It's simple, really. Once you've retired, the first thing you say to yourself is: oh well, so how much time have I got left?' (Joseph, 63 years old). This approximate calculation of how much time remains demonstrates the highest level of consciousness of the approach of death, 'moriturus' (I will die soon) according to Gagey (1989: 7). 
Furthermore, levels of consciousness of death are extremely variable. In fact, some participants were evasive when it came to this topic or kept putting their remaining time into perspective: 'I think that logically I've still got a few years ahead of me and I can still have experiences' (Marie-Danielle, 66 years old). Certain individuals therefore retained an open time horizon following retirement. This result, consistent with the literature on time horizons (Malas and Safraou, 2008) demonstrates the importance of measuring these differing levels of consciousness of the approach of death using an appropriate tool.

\section{The affective dimensions of UTP: non-mutually exclusive feelings}

Most likely due to embarrassment and/or socioemotional selectivity mechanisms (positivity effect $^{1}$ - Carstensen, 1991, 1992; Reed and Carstensen, 2012), retirees expressed fewer negative affective reactions (68 quotations) than positive affective reactions (128 quotations) in reference to their limited time remaining.

The end is near, which generates a certain anxiety owing to its unknown nature. Individuals do not know how much time they have left in their current state or how much time they have left to accomplish all they want to accomplish. 'What I'm afraid of is that I won't be able to go to the garden anymore, you see. That, well, it'd be tough, you know [...] I don't know how I'm going to manage, that's the hardest thing' (Mathieu, 74 years old). Such remarks are similar to Clément's assessments (2007) on concerns linked to the perceived lower quality of time left to live. This point, which is only briefly touched upon in the literature, in fact appears frequently in participants' responses. The majority of the individuals in question discuss the topic by comparing their time left with their time lived in the past. They are sad about having reached this life stage and express their sadness and melancholy: 'it's depressing to realise that he's already that old because, well, I suppose that means that it's the same for us' (Pierre-Jean, 77 years old). Indeed, individuals find it difficult to deal with the fact that they no longer have much time ahead of them, they experience regret and wish they could turn back the clock: 'That's how it is, we can't go back in time, and, well, there's nothing we can do' (Marie-Danielle, 66 years old). They appear to suffer through time as it passes: 'Time goes by and there's nothing we can do to stop it' (Jean, 75 years old). Hence a certain anxiety emerges linked to making the most of their time left: 'There are so many things that come into

\footnotetext{
${ }^{1}$ According to Reed and Carstensen (2012), the positivity effect is a distinctive feature of the cognitive process of older individuals: their memory and attention focus more on stimuli (information, images) that cause positive affective reactions (compared to stimuli that cause negative affective reactions).
} 
play, but in spite of everything, things holding you back, you have to do it, you have to do it, oh no, you mustn't wait' (Joseph, 63 years old).

These quotations supplement the relatively undetailed literature on the negative affects associated with the approach of death. Vergely (2010) briefly mentions the fact that older individuals can suffer due to the time they have left, yet this qualitative study pinpoints the affective reactions that can cause this suffering. Therefore, the negative affects related to a limited amount of time left to live include anxiety, fear of not having enough time ahead of oneself, and regret and sadness. When individuals realise that they have little time left, they regret how they spent their time in the past. This makes them sad as they believe it is already too late to complete certain projects or activities.

In contrast, as has been suggested for CTP, time constraints can have a stimulating effect (Lallement and Machat, 2011). In the context of UTP, the main positive affective reaction is enthusiasm, the pleasure found in savouring one's last moments. Individuals appear to be stimulated by the constraint of the final time limit into making the most of life, as mentioned in the literature (Marchand, Quéniart and Charpentier, 2010): 'As long as you've got the energy, as long as you're alive, as long as you want things. To want something, you have to be alive' (Françoise, 68 years old), to do what they want to do because soon it will be too late: 'Let's make the most of it because soon it will be our time to go' (Pierre-Jean, 77 years old).

The presence of these affective elements shows that the perception of time left to live resembles time pressure and not only a time horizon. Indeed, the cognitive and affective elements mentioned in the definition of UTP can be found. Moreover, the qualitative study provides results that are consistent with the present literature on ageing with regards to positive affective reactions. It also provides more detail on the negative affective reactions briefly touched on in such literature. In addition, both types of affective reaction often appear in the responses from the same individual in variable proportions. Such reactions are therefore not mutually exclusive (13 out of 18 participants display both affective reactions) in contrast to the literature on CTP (Machat and Lallement, 2011). This therefore responds to the issue at the end of the literature review: older individuals seem to exhibit psychological ambivalence regarding the affective reactions associated with the approach of death.

Given that the same individual can experience both types of affective reaction, it seems most likely that there are two emotional components. This also allows us to consider the possibility that individuals may not be affected by the reduction in their time left to live (a low score for 
both affective components would demonstrate a certain neutrality). This leads to a complete definition of the UTP construct: Ultimate time pressure is a psychological disposition that manifests itself in a cognitive dimension (consciousness of limited time left) and two affective dimensions (negative and positive).

A quantitative study was therefore necessary to verify the factorial structure of UTP as described above.

\section{CREATING A MEASUREMENT SCALE FOR ULTIMATE TIME PRESSURE}

The literature review allowed us to highlight the existence of the cognitive and affective elements of the perception of remaining time. This has led to the conclusion that this perception can be understood as a specific time pressure: UTP. However, to our knowledge, only the cognitive aspect of UTP has been the subject of a measurement scale (time horizon), which has, moreover, been considered to be non-operational (Malas and Safraou, 2008). In order to measure the different elements of the perception of time left to live and test its influence on the behaviour of older people, it is essential to develop an ultimate time pressure (UTP) measurement tool. To do so, Churchill's paradigm (1979) and Rossiter's recommendations (2011) have been used.

\section{Specifying the construct domain and generating items}

UTP has been defined as the realisation that one's time left to live is limited by death, the final time limit (cognitive aspect of UTP), and the affective reactions (feelings) that accompany this realisation (affective aspect of UTP). The qualitative study confirms and further refines the existence of these elements. This permits the development of a three-dimensional structure with regard to the non-mutual exclusivity of the affective reactions (both types of affective reaction can be present in one individual). A list of 66 reflective items was drawn up taking into account the three dimensions observed and the quotations associated with these dimensions (Rossiter, 2011).

The cognitive dimension refers to the consciousness of having a limited amount of time left to live. Words linked to thought are prevalent in the quotations representing this dimension: time goes by, the person thinks about it, is conscious of it. Verbs expressing the approach of this time limit (get closer, come), terms linked to death (death, passing), and to ageing (old, age) also appear. This dimension thus refers to the cognitive element of the perception of time left 
to live mentioned in the literature on time horizons, and allows us to answer the question 'Where am I in time (between my birth and my death)?', as discussed by Malas and Guiot (2008: 8). In this way, the generated items represent individuals' time horizons in order to measure the level of their consciousness of the approach of death.

The positive affective dimension is manifested in positive affects (enthusiasm, stimulation) with regard to the time remaining. Individuals perceive the time limit as an opportunity to make the most of things, which is noted in words such as 'take advantage of' or 'want'. Adjectives expressing wonder (beautiful, superb) show that, for such individuals, it is time to make the most of what the world has to offer before death catches up with them. These elements, found in both the literature and the qualitative study, have resulted in the generation of items that draw a parallel between time left to live and stimulation to savour such time in different ways.

The negative affective reaction appears in negative affects (sadness, fear) with regard to the limited time left. Verbs in the past tense in the quotations that come under this dimension demonstrate individuals' tendencies to compare life stages, making this dimension similar to the concept of regret as set out by Clément (2007). In the literature, regret is defined as being linked to a comparison between reality and what could have been, following an 'if... then' kind of logic (Delacroix and Jourdan, 2007). If, for example, retirees had known that time would pass this quickly, then they would have used their time differently when they were young and would not feel such a strong need to make the most of it now. Fearing a lack that will be felt even more strongly in the future, they struggle to deal with their position in their lifecycle and would like to turn back the clock to have more time ahead of them. Nonetheless, they are conscious that this is not possible, which refers to the notion of 'unrecoverable costs', that is generally associated with regret (Zeelenberg, 1999: 328). These analyses led to the generation of items that compare remaining time and time lived.

The items were assessed by five established researchers (specialists in old age or experts in creating measurement scales) to determine if they were representative (Jolibert and Jourdan, 2011b) and a pre-test was then conducted with retirees. This led to the generation of 39 items, which covered all dimensions equally and had the highest degree of content validity (Appendix 1).

\section{Purification and validation of the measurement scale}




\section{Data collection methodology}

Data collection (with preliminary questionnaire pre-test) was conducted twice (appendix 2: sociodemographic characteristics). The aim of the initial data collection (January 2013; 215 questionnaires) was to purify the UTP measurement scale and to test the specific measurement tools. The aim of the second data collection (April 2013) was to confirm the factorial structures (in part of the sample: 180 individuals) and to test the scale reliability and validity (in the rest of the sample: 333 individuals). The self-report method was preferred in view of the personal nature of the responses. Participants, recruited in situ (community spaces, universities of the third age) or online (forums, emails to charitable associations) were asked to state to what extent they agreed with the items. As the internet is increasingly familiar to older people (Boulbry et al., 2012; Chevalier et al., 2013), participants were able to complete the questionnaire using a hard copy or online.

\section{Exploratory and confirmatory factorial analysis}

PCA was carried out on samples no. $1(\mathrm{~N}=211, \mathrm{KMO}=0.86)$ and no. $2(\mathrm{~N}=180, \mathrm{KMO}=$ 0.82) using SPSS 20 software. As the items were designed to reflect the dimensions of a single concept (UTP), Oblimin rotation was chosen (Hair et al., 2010). In both samples, a framework structured around three dimensions seems most feasible. After successive purifications, the factorial structure took shape (final scale: 11 items, explained variance 63\%), and was confirmed by CFA, using EQS 6.1 software. The three dimensions: cognitive, positive affective and negative affective thus appear to be stable. The factorial structure set out in the complete definition of UTP is therefore validated.

The strong correlation between the dimensions encouraged us to test the possibility of a second-order model. Exploratory analysis highlighted only one higher-order factor. It is, therefore, possible to draw on the second-order latent construct (UTP in the general sense of the term), as well as considering its three dimensions at a lower level of abstraction. First and second order CFA provided fit indices that were reasonably equivalent to or higher than those from alternative models (table 2). Moreover, standardised loadings were significant and above 0.5 (appendix 3: factorial structure).

\section{< Insert table 2 - Results of exploratory and confirmatory factorial analyses >}

\section{Measurement scale reliability and validity}

The psychometric properties of the measurement tools were verified with sample no. 3 . The scale proved to be reliable ( $\alpha$ and $\rho$ Jöreskog $>0.7$ ). Concerning convergent validity, the 
loadings and $\mathrm{Z}$ test were above the commonly acceptable thresholds, whereas $\rho_{\mathrm{vc}}$ was close to 0.5. Therefore, in accordance with Delacroix and Jourdan (2007: 36) and observing $\rho_{\mathrm{vc}}$ at between 0.4 and 0.5 for certain dimensions of the consumer tendency to regret scale, the results can be considered: 'satisfying in the context of an initial approach'.

To determine the discriminant validity of the UTP scale, the death anxiety scale (Urien, 2002) and CTP scale (Machat and Lallement, 2011) were used (appendix 4). No problems emerged regarding the death anxiety scale. Concerning the CTP scale, an item written to reflect the affective dimension was too closed to cognitive items. This inversely oriented item probably caused problems for the oldest individuals. As two-item constructs are not advised in structural equation modelling (Hair et al., 2010), only the cognitive dimension of CTP has been retained. The theoretical proximity between the constructs is demonstrated by the strong correlations. Nonetheless, the discriminant validity was proven (table 3).

\section{< Insert table 3 - UTP scale reliability and validity >}

The section below, which focusses on the influence of UTP on motivations to volunteer, will permit the verification of the nomological validity of the scale.

\section{STUDYING THE INFLUENCE OF UTP ON RETIREES' MOTIVATIONS TO VOLUNTEER}

Nomological validity concerns the relationship between the measured concept (UTP) and other concepts that logically stem from it (Jolibert and Jourdan, 2011b), in this case, motivations to volunteer. Below, after explaining why this area has been chosen, nomological validity will be tested using structural equation modelling.

\section{Usefulness of UTP as an explanatory variable of motivations to volunteer}

Volunteering can fulfil an important psychological function following the significant ageingrelated changes experienced by retirees (Talpin, 2013). Volunteering can lead to a successful ageing process as it is a means of bringing people together (Fontaine, 2007). In reality, however, individuals are generally not highly motivated to volunteer when they enter retirement (Cerphi, 2012). This may be due to the fact that certain associations assign tasks to retired volunteers that require the largest time commitment (Van Ingen and Dekker, 2011), disregarding their motivations, on the grounds that they have more time available. Yet, the surge in free time experienced by retirees in fact leads to a negligible increase in the time they 
allocate to volunteering (Mutchler et al., 2003; Prouteau and Wolff, 2007). Furthermore, some retirees are concerned about committing to a time-consuming activity (Tang et al., 2009). These assessments lead to the conclusion that the perception these individuals have of their time left to live may play a role in the development of motivations to volunteer. The literature is largely focused on classifying such motivations (Chantal and Vallerand, 2000; Clary et al., 1996; Okun et al., 1998) and not their determinants, but some research focusses on the development of these motivations according to age (Haski-Leventhal, 2009; Morrow-Howell, 2010; Okun et al., 1998). Some of these studies (Dávila and Díaz-Morales, 2009; Okun and Schultz, 2003; O’Neill et al., 2011) have applied socioemotional selectivity theory (Carstensen, 1991), justified a posteriori by certain results, notably relating to the relationship between age and relational motivations (experiencing positive emotions as a benefit of action). However, in the research that uses this theory, volunteers were not asked about how they perceived their time left to live. For this reason, Dávila and Díaz-Morales (2009) mention the importance of including variables that measure this perception of time left (such as time horizons). It is therefore interesting to use UTP to explain why retirees volunteer, which is what is tested below.

\section{Influence of UTP on retirees' motivations to volunteer: empirical test}

There are various conceptions of volunteers' motivations and there is a corresponding measurement scale for each conception and its supporting theory (for an overview of the different approaches, see appendix 5). Chantal and Vallerand's approach (2000) and the resulting Volunteering Motivation Scale (VMS) is a good compromise between the different conceptions as it combines the level of altruism/egoism and the level of self-determination (origin of motivation: choice/constraint). Therefore, the items generated for VMS that reflect two opposing motivations (self-determined egoism and non self-determined altruism) were integrated into the questionnaire (appendix 4).

- Self-determined egoism (origin: self; beneficiary: self) is a desire to carry out a voluntary activity to gain something from it (e.g., wellbeing, increase in self-esteem, relationships). The aforementioned studies on this topic (Dávila and Díaz-Morales, 2009) allow us to suggest that there is a positive relationship between the positive affective dimension of UTP and motivations to volunteer. In fact, this dimension encourages individuals to make the most of their remaining time by engaging in activities that they enjoy and do them good. The 
qualitative study shows that volunteering can be one of these activities: 'I am very happy to spend my time in that way, because there is a good rapport, because it's fun [...] I don't know what the future holds, but for me, as long as I'm alive, I'll keep going' (Françoise, 68 years old). Therefore, volunteering can be understood as a response to the desire to make the most of life that is discussed in the literature, and that corresponds to the positive affective dimension of UTP. This leads to hypothesis H1: The positive affective dimension of UTP positively influences self-determined egoistic motivations.

However, according to Tang et al. (2009), retirees do not want to commit to a time-consuming activity. The literature on ageing provides an insight into this stance. Indeed, it states that the desire to make the most of life is associated with the approach of death. The latter leads to a desire not to 'waste' the precious time remaining (Szmigin and Carrigan, 2001; Warburton and Crosier, 2001). Retirees are conscious that they no longer have much time ahead of them, which pushes them to keep it for themselves: 'I would like to have, to have more time available for my little egoistic self' (Marie-Paule, 62 years old). Therefore, although volunteering may be enjoyable, being conscious of having limited time left to live can restrict enthusiasm for getting involved. Hence H2: The cognitive dimension of UTP negatively influences self-determined egoistic motivations.

- Non self-determined altruism (origin: others; beneficiary: others) is a social/moral obligation to engage in a voluntary activity to help others. This motivation, in contrast to the former, is logically underpinned by the negative affective dimension of UTP. Indeed, in the later stages of development, certain individuals neglect themselves (Erikson, 1959) by fully focussing on others (self-sacrifice), particularly in the event of a 'negative life review' (Talpin, 2013: 43). Retirees that are negatively affected by their reduced time left to live, therefore, regret the time they lost and the way in which they spent their time in the past. Volunteering consequently becomes their way of carrying out their moral duty, using the time they have left to help others, as the constituent narcissistic elements of the self are broken down by ageing: ' $I$ will experience the same fate of people that age. I find that saddening, but that's the way it is. With volunteering, it's almost a social necessity to take part in what is happening around you and to do what you can to try [...] to take part in what is happening in society' (Marie-Paule, 62 years old). This leads to H3: The negative affective dimension of UTP has a positive relationship with non self-determined altruistic motivations.

These hypotheses are then tested using structural equation modelling (figure 1). 


\section{< Insert figure 1 - Influence of UTP on retirees' motivations to volunteer >}

$\mathrm{H} 1$ and $\mathrm{H} 2$ are validated. Rationally speaking, being conscious of a limited time left to live would make individuals reluctant to give away their time, whereas the positive affects linked to this constraint push individuals towards volunteering to make the most of their time in the company of others.

These conclusions contribute to the theoretical framework of socioemotional selectivity by adding additional information: if older individuals choose to volunteer to gain something positive, the shortening of their time horizon (cognitive dimension of UTP) is not at the root of these motivations (these two constructs have a negative relationship); instead, the stimulating sensation that accompanies this activity (positive affective dimension of UTP) is the cause.

Hypothesis H3, related to the influence of the negative affective dimension on non self-determined altruistic motivations, is also validated. Retirees, negatively affected by the approach of death, show signs of self-sacrifice. Their selves disappear, to the benefit of others, of their communities, as if they hope to repay society for what it gave them. The individual thus anticipates the 'mourning of the self' addressed by Thomas (1989: 127).

CONTRIBUTIONS, MANAGERIAL IMPLICATIONS, LIMITATIONS AND RESEARCH AVENUES

The contributions, limitations and avenues of research opened up by this article concern the concept of UTP and its scope (managerial implications), to a lesser degree.

\section{Theoretical contributions}

This research will enrich the literature by contributing to both the work on ageing and research on time pressure.

Ageing and the three-dimensional structure of the perception of time left to live By studying the existing literature and the various datasets collected, this research demonstrates that the time horizon concept is incomplete. It focusses on the cognitive aspects linked to the individual's perceived position of where they are in the timeframe between their birth and death, disregarding what they may feel when confronted with the approach of death. However, whether or not affective reactions associated with these cognitive elements exist necessary to define not only a (limited) time horizon, but a specific time pressure (Lallement, 
2010; Szollos, 2009) - is yet to be determined. This research can thus make a theoretical contribution by showcasing and measuring the affective aspects integral to UTP. Moreover, some researchers have underlined the lack of temporal criteria to categorise older individuals (Moschis and Nickell, 2012), and the shortage of adequate measurement tools. Consequently, one of the challenges of this research has been to propose a measurement tool that is able to measure the concept of ultimate time pressure defined above. Furthermore, it was important to avoid the content validity problems discovered by some authors (Malas, 2009; Malas and Safraou, 2008) in Carstensen and Lang's time horizon scale (1996), which predates Rossiter's recommendations $(2002,2011)$ on this topic.

To this end, an interdisciplinary literature review and an additional qualitative study were necessary to create a measurement scale representing all elements of the perception of time left to live. More specifically, the various analyses have resulted in a three-dimensional construct (a cognitive component, a positive affective component and a negative affective component). This structure appears to be consistent with the literature while shedding light on the affective reactions linked to the approach of death, which have not yet been addressed in any great depth in the field.

The cognitive component of UTP reflects the cognitive aspect of the perception of time left to live, which has already been addressed in the literature on ageing using the time horizon concept. Consequently, four items tackle the notion of the consciousness of the proximity of death and its approach as an individual ages (Caradec, 2008; Gagey, 1989). In addition, the qualitative study made it possible to confirm the existence of individual differences in the level of consciousness of the approach of death, addressed in socioemotional selectivity theory (Carstensen, 1991). The items thus allow us to measure to what extent older individuals are conscious of death drawing near, that is, the length of their time horizon and nothing more, therefore compensating for the limitations of Carstensen and Lang's scale (1996) underlined by Malas and Safraou (2008).

The two other components are of an affective nature and thus supplement the time horizon concept, which does not address the feelings of individuals confronted with their perceived proximity of death.

The positive affective component reflects the new lease of life associated with the proximity of death mentioned in the literature on ageing (Marchand, Quéniart and Charpentier, 2010; Wiedmer, 2010). The qualitative study allows us to clarify the nature of this affective 
component: the desire to make the most of life seems to be central, as if individuals were stimulated by their last opportunity to accomplish everything that they were still able to accomplish. The desire to live one's last moments fully translates into the items covering this dimension. By drawing a parallel between this stimulation and the consideration of the passing of time, the idea of time pressure emerges. Indeed, these positive affects accompany thoughts related to a time constraint, as for all kinds of time pressure: individuals wish to make the most of the time remaining as it is limited. While it seems that the literature has already underlined this strong relationship between cognition and positive affects linked to time left to live (e.g. Marchand, and Quéniart and Charpentier, 2010: 67 refer to the fact that older individuals want to make the most of life by bearing in mind that they will not 'last forever'), no measurement tool has allowed these positive affects to be understood until now. The negative affective component has been dealt with briefly in the literature. In fact, certain scholars underline the existence of negative affective reactions associated with the general idea of death (Bianchi, 1987), or of one's own death (Urien, 2002, 2003). Yet, what about the reactions associated with the perceived proximity of one's own death? Research has listed a range of negative affective reactions associated with the approach of death, such as the fear of running out of time before dying (De Hennezel, 2010), and sadness and regret (Clément, 2007). One's remaining time can therefore cause suffering (Vergely, 2010). The qualitative study has allowed us to clarify the role of these interconnected negative affective reactions. Regret seems to be linked to time that was lost when individuals were younger, to the impression of having wasted time, at a time when their days were not yet 'numbered'. Individuals therefore feel sad and anxious at the idea of picturing the time they have left: sad about their stage in life and the impossibility of turning back the clock, and anxious about what they will be able to accomplish in the limited time before death. The items covering this dimension thus reflect these different affective reactions associated with remaining time, in contrast to time lived in the past.

\section{Ultimate time pressure as a third time pressure category}

Regarding time pressure, this research can add to the existing categories. Indeed, time pressure as a variable has been clarified relatively recently (Lallement, 2008, 2010; Lallement and Machat, 2011; Machat and Lallement, 2011). This research does not address the possible feelings associated with death's approach and has consequently been limited to exploring 
situations in the lives of individuals when time is limited. As a result, two principal categories have generally been identified until now:

- STP (Lallement, 2008, 2010): the short-term time pressure experienced by an individual when faced with a time limit in the relatively close future (e.g.: having to buy a present for someone's birthday, the end of a special offer).

- CTP (Lallement and Machat, 2011; Machat and Lallement, 2011; Szollos, 2009): the longterm time pressure reflecting an individual's observation of not having enough time on a daily basis and the affective reactions that accompany it (stimulation or frustration).

However, death can be understood as a time limit (the final time limit) and can therefore create time pressure when individuals realise it is approaching. Ultimate time pressure as neither situational, nor chronic, appears to be an additional category. Indeed, the dichotomy created by situational and chronic time pressures has never been believed to be an exhaustive list of types of time pressure. This research enables the addition of a new category: ultimate time pressure. UTP relates to a specific time limit (one's own death) and lasts from the moment an individual becomes conscious of death's approach to the moment an individual passes away.

\section{Practical implications}

UTP has initially been applied to volunteering. This research can therefore advise associations attempting to recruit long-term retired volunteers to combat high volunteer turn-over (Cerphi, 2010). Indeed, this research demonstrates a link between the positive dimension of UTP and self-determined egoistic motivations (relationships, novelty, wellbeing, etc.). It would therefore be beneficial to integrate the positive aspects of time left to live into any recruitment materials by referencing a 'new life' or 'time to flourish'. Such elements also recall Schau, Gilly and Wolfinbarger's 'identity renaissance' (2009), that is, the rebirth of consumer identity following the disappearance of professional identity among retirees. Therefore, the 'consumption' of volunteering experiences would allow such a renewal and add new elements to retirees' life-histories. Referring to the affective dimension of UTP, in relation to tasks such as organising cultural or sporting events, could therefore attract retirees looking for experiences that are enriching on a psychosocial level.

In contrast, emotionally negative UTP creates volunteers driven by a moral obligation to help those around them. Consequently, presenting retirement as a time that can be used to help 
others could be useful for promoting voluntary activities, such as 'food drives' or collecting clothing donations, underpinned by the duty to give back to society.

As the nomological validity test proved conclusive, a more complete model would allow us to integrate a larger spectrum of motivations (Chantal and Vallerand, 2000) and identify moderator variables. Depressive states associated with events linked to ageing (Fontaine, 2007), such as grief and illness, could have a moderator effect on the relationship between UTP and motivations to volunteer, insofar as they may hinder any motivation to act. The attitude of actors or reactors with regard to time (Bergadaà, 1990; Bergadaà and Urien, 2008 on donating items), which measures how individuals anticipate their future, could have a moderating role in the relationship between motivations and volunteering behaviours.

Lastly, generativity, featured in previous research on volunteering among retirees (Gourmelen and Guillemot, 2012), could be considered in addition to UTP. This would allow volunteering to be better understood as a behavioural response to the developmental challenges of the later stages set out in Erikson's theory (1959).

\section{Limitations and future avenues of research}

\section{Extending the study to other populations}

The UTP measurement scale was constructed using a sample of French retirees. However, despite the supposed universality of Carstensen's socioemotional selectivity theory (Malas and Safraou, 2008), culture influences how people think about time. In Western cultures, time is thought of as a straight line or an arrow, whereas in Eastern cultures, it is believed to be circular or cyclical, like the seasons (Adjaye, 2002; Usunier and Valette-Florence, 2007). Yet, UTP is associated with an individual's perceived position on a linear timeline. Is UTP similar in individuals with a cyclical perception of time?

Moreover, given the reliability and validity of the scale, it would be interesting to study the intensity of UTP in individuals of different age groups. For example, is UTP present in relatively young individuals that have experienced events characteristic of ageing (e.g., the death of parents or of friends from their own generation)? More highly developed projective tests may prove necessary, in addition to completing the questionnaires in person, in order to verify whether or not these individuals' defence mechanisms are so effective that the effects of UTP cannot be felt. Indeed, older individuals talk more freely about death than younger individuals (as death anxiety is higher at around 40 years of age - Urien, 2003). 
In line with the above conclusion regarding the possible existence of UTP in younger individuals, the results obtained from the discriminant validity test encourage us to embed UTP in a more comprehensive nomological network. Although the variables mentioned above constitute future avenues of research on volunteering, other concepts outside this field could also be investigated. Indeed, this research shows that retirees have different understandings of death. How can we explain these differences? The strong relationships between UTP, death anxiety and fear of ageing encourage us to carry out more in-depth studies on how these concepts are connected. Could death anxiety and fear of ageing be considered to be antecedents of UTP? For example, are individuals that develop high death anxiety before retirement more likely to experience the negative affects linked with the approach of death than others? Other personality traits that are stable over time, such as sensitivity to regret (Schwartz et al., 2002), could also explain the predominance of the negative affective dimension of UTP in certain individuals, as UTP relates to regrets associated with lost time.

\section{Managerial scope of UTP}

The managerial implications of this research principally concern the area studied: voluntary work carried out by retirees. An interesting avenue of research would involve developing the operational scope of the UTP construct itself. To this end, a typology of retirees based solely on the three dimensions of UTP could divide these individuals into generic types according to their perception of time left to live. This research shows that the three dimensions of UTP are present in retirees to varying extents and can influence their behaviour in different ways. A typology would allow us to determine whether or not profiles of retirees characterised by one or two dominant dimensions exist. This would facilitate the targeting of retirees by any organisations. Could some individuals experience a version of UTP in which cognition is dominant? In other words, could some individuals be relatively indifferent to the approach of death? Although the qualitative study has demonstrated the existence of psychological ambivalence in the majority of participants, could some retirees be dominated by positive or negative affective reactions? The underlying idea behind creating a typology would be to facilitate the targeting of retirees and communicate a message about time left to live - which is rather delicate to implement - by categorising profiles dominated by different dimensions of UTP and by characterising them with the help of sociodemographic variables.

Furthermore, the influence of UTP should be tested in areas other than volunteering in order to develop its managerial scope. Retirees' financial choices, notably choosing between 
spending and saving, have already been studied from a time perspective with the 'time horizon' variable (Malas and Guiot, 2008; Malas and Safraou, 2008; Malas, 2009). However, in addition to the influence of the perceived proximity of death, it would be interesting to examine the impact of the associated positive and negative affective reactions on financial decisions among older people. For example, the positive affective dimension, which echoes a desire to make the most of the remaining time, could influence purchasing decisions (trips, leisure) among retirees, to the detriment of any savings intended for future generations. The importance of a typology based on the perception of time left to live in association with the perception of money would make perfect sense when applied to this field of research. 


\section{Appendix 1: Generated items retained following the purification process and expert}

\section{assessment}

The following table contains the items that passed the validity content step and were then removed at the purification stage. The letter E means that the item was eliminated following principal component analysis, the letter $\mathrm{C}$ means that the item was kept (sample no. 3 is not listed as all items were retained following PCA performed on this sample). The items in bold feature in the final factorial structure.

\section{Item wording}

\begin{tabular}{|c|c|}
\hline Sample & Sample \\
1 & 2 \\
\hline
\end{tabular}

\section{Cognitive dimension}

At my age, you expect to die in the near future

I believe I still have a lot of time ahead of me (inverse)

As I'm getting older, I'm starting to realise that my time is running out

At my age, the future comes down to a few years

I think that the end of my life is near

I'm still too young to be thinking about dependency (inverse)

The older I get, the more I tell myself that death is approaching

I avoid thinking about the time I have left to live (inverse)

How many years do I have left? Is a question I ask myself often

Positive affective dimension

I'm getting older, so as long as I've still got the energy, I make the most of it by doing what I like

It does not matter that time is passing, I feel better than ever

When you have life ahead of you, you are always chasing something. As you age, you take things more steadily

Health hangs by a thread, so at my age, I mustn't wait too long to get certain things done.

As long as you are alive, you must keep your enthusiasm for life no matter what happens.

When you see the end drawing near, it motivates you to make the most of life

The benefit of getting older is savouring the time we have for ourselves until the end

I like living one day at time, as life could stop from one day to the next

Thinking about time passing encourages me to fulfil my desires

Given the time I have left, I think of the future as a series of happy moments spent with my loved ones

Thinking about the end of my life allows me to fully experience the present moment

The older I get, the more I am free from time constraints

Retirement is the time to live a little before it is too late

Negative affective dimension

Thinking about time passing is unpleasant, especially once you're past a certain age

Seeing the children grow up so quickly makes me feel down

Having to take it easy when I get older scares me

It makes me sad to think that my pace of life will slow down over the years

Thinking about the years I have left makes me feel uneasy

I feel sad when I realise that I am already this old

When I think about how old I will be in five years, it doesn't make me happy

I regret not finishing certain projects when I still had the time

If I'd have known that time would pass this quickly, I would have made the most of it more when I was younger

The fact that life goes by so quickly frightens me

It makes me sad when I think about certain activities that I can no longer do

I wish I could get back all the time I lost in the past, as I'm afraid that I won't have enough.

We should not get older, it is too sad

I'm scared of being less and less able to be active as I get older

Time passes so quickly, unfortunately we would need multiple lives to do everything we want to do

I'm scared that I will not be able to do everything I need to do before I die

I feel pressured into doing certain things before it is too late

\begin{tabular}{|c|c|}
\hline $\mathrm{C}$ & $\mathrm{C}$ \\
\hline $\mathrm{C}$ & $\mathrm{E}$ \\
$\mathrm{E}$ & \\
\hline $\mathrm{C}$ & $\mathrm{C}$ \\
$\mathrm{C}$ & $\mathrm{C}$ \\
\hline $\mathrm{E}$ & \\
$\mathrm{C}$ & $\mathrm{C}$ \\
\hline $\mathrm{E}$ & \\
\hline $\mathrm{E}$ & \\
\hline
\end{tabular}

E

E

E

$\mathrm{E}$

\begin{tabular}{l|l}
$\mathrm{E}$ & \\
$\mathrm{E}$ & \\
$\mathrm{C}$ & $\mathrm{C}$ \\
\hline
\end{tabular}




\section{Appendix 2: Participants' sociodemographic characteristics}

\begin{tabular}{|c|c|c|c|}
\hline & $\begin{array}{c}\text { Sample } 1 \\
(\mathrm{~N}=221)\end{array}$ & $\begin{array}{c}\text { Sample } 2 \\
(\mathrm{~N}=180)\end{array}$ & $\begin{array}{r}\text { Sample } 3 \\
(\mathrm{~N}=333)\end{array}$ \\
\hline \multicolumn{4}{|c|}{ Age } \\
\hline Average age & 68 years old & 66.3 years old & 67.2 years old \\
\hline Standard deviation & 6.739 & 4.980 & 5.75 \\
\hline Minimum & 54 years old & 55 years old & 54 years old \\
\hline Maximum & 87 years old & 83 years old & 87 years old \\
\hline \multicolumn{4}{|c|}{ Gender } \\
\hline Male & $49.3 \%$ & $52.8 \%$ & $50.2 \%$ \\
\hline Female & $50.7 \%$ & $46.7 \%$ & $49.8 \%$ \\
\hline Undisclosed & $0 \%$ & $0.6 \%$ & $0 \%$ \\
\hline \multicolumn{4}{|c|}{ Level of education* } \\
\hline Primary education & $2 \%$ & $2.2 \%$ & $2 \%$ \\
\hline $\begin{array}{l}\text { Brevet exams (taken at } 14-15 \text { years of } \\
\text { age) }\end{array}$ & $13 \%$ & $8.9 \%$ & $8 \%$ \\
\hline BEP, CAP (vocational qualifications) & $22 \%$ & $16.7 \%$ & $19 \%$ \\
\hline $\begin{array}{c}\text { BAC and BAC level (secondary } \\
\text { education qualifications) }\end{array}$ & $18 \%$ & $23.9 \%$ & $18 \%$ \\
\hline $\begin{array}{c}\text { 1,2 and 3-year higher education } \\
\text { qualifications }\end{array}$ & $27 \%$ & $28.3 \%$ & $27 \%$ \\
\hline $\begin{array}{c}\text { 4-year and over higher education } \\
\text { qualifications }\end{array}$ & $18 \%$ & $19.4 \%$ & $26 \%$ \\
\hline Undisclosed & $0 \%$ & $0.6 \%$ & $0 \%$ \\
\hline \multicolumn{4}{|c|}{ Retirement status** } \\
\hline Retired & $100 \%$ & $100 \%$ & $100 \%$ \\
\hline Not retired & $0 \%$ & $0 \%$ & $0 \%$ \\
\hline
\end{tabular}

* The level of education appears to be relatively high in view of the age of the studied population. This seems to be consistent with the literature on the subject (Erlinghagen and Hank, 2005; Zedlewski and Schaner, 2006), that states the level of education is higher in older volunteers.

**Note there was no age limit for participating in the study. The only condition for participating in the research was to be retired. Therefore, all participants, even those under 60 years of age (in the minority: $5.8 \%$ of the entire sample), are retired. 
Appendix 3: Factorial structure, UTP scale, samples no. 2 and 3

\begin{tabular}{|c|c|c|c|c|c|c|}
\hline \multirow[b]{3}{*}{$\begin{array}{l}\text { I wish I could get back all the time I lost in the } \\
\text { past, as I'm afraid that I won't have enough }\end{array}$} & \multicolumn{6}{|c|}{ Component } \\
\hline & \multicolumn{2}{|c|}{$\begin{array}{l}1 \text { (negative } \\
\text { affective) }\end{array}$} & \multicolumn{2}{|c|}{2 (cognitive) } & \multicolumn{2}{|c|}{$\begin{array}{l}3 \text { (positive } \\
\text { affective) }\end{array}$} \\
\hline & $0.805^{*}$ & $0.81 * *$ & & & & \\
\hline $\begin{array}{l}\text { I regret not finishing certain projects when I } \\
\text { still had the time }\end{array}$ & 0.777 & 0.62 & & & & \\
\hline $\begin{array}{l}\text { If I had known that time would pass this } \\
\text { quickly, I would have made the most of it } \\
\text { more when I was younger }\end{array}$ & 0.772 & 0.69 & & & & \\
\hline $\begin{array}{l}\text { I am scared that I will not be able to do } \\
\text { everything I need to do before I die }\end{array}$ & 0.680 & 0.58 & & & & \\
\hline $\begin{array}{l}\text { At my age, you expect to die in the near } \\
\text { future }\end{array}$ & & & $0.877 *$ & $0.82 * *$ & & \\
\hline I think that the end of my life is near & & & 0.783 & 0.75 & & \\
\hline $\begin{array}{l}\text { At my age, the future comes down to a few } \\
\text { years }\end{array}$ & & & 0.755 & 0.80 & & \\
\hline $\begin{array}{l}\text { The older I get, the more I tell myself that } \\
\text { death is approaching }\end{array}$ & & & 0.684 & 0.62 & & \\
\hline $\begin{array}{l}\text { When you see the end drawing near, it } \\
\text { motivates you to make the most of life }\end{array}$ & & & & & $0.849 *$ & $0.78 * *$ \\
\hline $\begin{array}{l}\text { Thinking about the end of my life allows me } \\
\text { to fully experience the present moment }\end{array}$ & & & & & 0.791 & 0.77 \\
\hline $\begin{array}{l}\text { Thinking about time passing encourages me to } \\
\text { fulfil my desires }\end{array}$ & & & & & 0.784 & 0.75 \\
\hline
\end{tabular}

*PCA loading matrix sample no. 2

**Second order CFA standardised loadings sample no. 3. 


\section{Appendix 4: Measuring other constructs}

Chronic time pressure (CTP - Machat and Lallement, 2011)

Cognitive dimension $(\alpha=0.71 ; \rho=0.71 ; \rho v c=0.49)$

I experience significant time pressure in my life

I feel pressed for time when I go shopping

When do you feel pressed for time? (from always to never)

Affective dimension (not taken into account, reduced to 2 items)

I did not choose to be pressed for time [inverse item] - eliminated following PCA

It is my choice to be pressed for time

I prefer being pressed for time

Death anxiety (Urien, 2002)

Death anxiety $(\alpha=0.89 ; \rho=0.90 ; \rho v c=0.63)$

The idea of my own death depresses me

I am scared of dying

The idea of my own death makes me feel anxious

The idea of being dead scares me

I imagine my own death as a painful and nightmarish experience

Motivations to volunteer (adapted from VMS, Chantal et Vallerand, 2000)

Self-determined egoism (SE); $(\alpha=0.75 ; \rho=0.71 ; \rho v c=0.50)$

For the pleasure of experiencing new things when I volunteer

For the satisfaction of exploring new fields when I volunteer

Because volunteering allows me to meet new groups of people

Non self-determined altruism (NSA) $(\alpha=0.78 ; \rho=0.71 ; \rho v c=0.55)$

Because if I did not volunteer, I would feel guilty

Because I would feel ashamed if I did not help others

Because I would be uneasy if I did not do it 


\section{Appendix 5: Measurement of motivations to volunteer using Chantal and Vallerand's approach (2000)}

\begin{tabular}{|c|c|c|c|c|}
\hline Scale & $\begin{array}{l}\text { Volunteer Functions } \\
\text { Inventory (VFI, Clary and al., } \\
\text { 1996) }\end{array}$ & $\begin{array}{l}\text { Volunteering } \\
\text { Motivation Scale } \\
\text { (VMS, Chantal and } \\
\text { Vallerand, 2000) } \\
\end{array}$ & $\begin{array}{l}\text { Motivations for sports } \\
\text { volunteerism (Wang, } \\
\text { 2004) }\end{array}$ & $\begin{array}{l}\text { Motivation at work scale } \\
\text { revised (MAWS-R) Gagné et } \\
\text { al., } 2015\end{array}$ \\
\hline Discipline & Psychology & Psychology & Marketing & Psychology \\
\hline $\begin{array}{l}\text { Theoretical } \\
\text { basis }\end{array}$ & $\begin{array}{l}\text { Functionalist theory (a } \\
\text { volunteer can pursue various } \\
\text { goals and two individuals can } \\
\text { take part in the same activity } \\
\text { without necessarily sharing the } \\
\text { same motivations) }\end{array}$ & $\begin{array}{l}\text { Self-determination } \\
\text { theory (volunteering by } \\
\text { choice or necessity) }+ \\
\text { dichotomy of } \\
\text { altruistic/egoistic } \\
\text { motivations }\end{array}$ & Functionalist theory & Self-determination theory \\
\hline $\begin{array}{l}\text { Positive } \\
\text { points }\end{array}$ & $\begin{array}{l}\text { Popularity (numerous tests), } \\
\text { simplicity. }\end{array}$ & $\begin{array}{l}\text { Takes into account } \\
\text { both the origin of the } \\
\text { motivation and } \\
\text { beneficiary of the } \\
\text { action. }\end{array}$ & $\begin{array}{l}\text { Using psychological } \\
\text { theories in marketing }\end{array}$ & $\begin{array}{l}\text { Demonstrates the existence of } \\
\text { renewed interest in self- } \\
\text { determination theory in } \\
\text { research }\end{array}$ \\
\hline Limitations & $\begin{array}{l}\text { Some authors group the scale } \\
\text { dimensions according to } \\
\text { criteria linked to the level of } \\
\text { altruism/egoism (Agostinho } \\
\text { and Paço, 2012) or the level of } \\
\text { self-determination } \\
\text { (Finkelstein, 2009). }\end{array}$ & $\begin{array}{l}\text { Extremely complex } \\
\text { division of levels of } \\
\text { self-determination. } \\
\text { Levels need to be } \\
\text { collated. }\end{array}$ & $\begin{array}{l}\text { Too specific to } \\
\text { volunteering at sporting } \\
\text { events. } \\
\text { Mix of items addressing } \\
\text { current motivations (e.g., } \\
\text { 'I volunteer because I } \\
\text { like helping others'); } \\
\text { future motivations (e.g., } \\
\text { 'I would like to take part } \\
\text { in the event') and } \\
\text { opinions (e.g., } \\
\text { 'volunteering provides a } \\
\text { service to the } \\
\text { community') }\end{array}$ & $\begin{array}{l}\text { Scale used by some } \\
\text { researchers (Haivas, Hofmans } \\
\text { and Pepermans, 2012; Bidee } \\
\text { et al., 2013) to measure } \\
\text { motivations to volunteer but } \\
\text { initially created to measure } \\
\text { motivations to work. } \\
\text { Consequently, it only refers to } \\
\text { the level of self-determination } \\
\text { and not the level of } \\
\text { altruism/egoism. }\end{array}$ \\
\hline Decision & $\begin{array}{l}\text { Not retained: with regard to } \\
\text { the groupings of dimensions } \\
\text { observed in the literature, } \\
\text { using a scale based on self- } \\
\text { determination theory seems } \\
\text { the better choice }\end{array}$ & $\begin{array}{l}\text { Retained } \\
\text { simplification of the } \\
\text { levels of self- } \\
\text { determination (self- } \\
\begin{array}{l}\text { determined/non self- } \\
\text { determined) }\end{array}\end{array}$ & $\begin{array}{l}\text { Not retained owing to the } \\
\text { limits listed above }\end{array}$ & $\begin{array}{l}\text { Not retained as it is less } \\
\text { complete than Chantal and } \\
\text { Vallerand's scale (2000), but } \\
\text { it validates our decision of } \\
\text { which theory to apply. }\end{array}$ \\
\hline
\end{tabular}

In brief, there are various measurement scales for motivations to volunteer. VFI (Clary et al., 1996) appears to be the most popular in the literature. However, it neglects the motivation origin criteria (choice or necessity). In addition, certain researchers that apply it create item groups using criteria similar to those of the VMS, notably the level of altruism/egoism (Agostinho and Paço, 2012) or the intrinsic/extrinsic nature of motivations (Finkelstein, 2009), which result from self-determination theory. This theory also seems to have been the subject of renewed interest in research on volunteering (Bidee et al., 2013; Haivas, Hofmans and Pepermans, 2012). However, such research makes use of a measurement tool that is not specific to volunteering, the Motivation At Work Scale - Revised (MAWS-R; Gagné et al., 2015). As the name of this scale indicates, it was originally designed to measure motivation at work. To our knowledge, only VMS (Chantal and Vallerand, 2000) combines the altruism/egoism and self-determination criteria, which explains why it was chosen for this research. 
Table 1 - Distinctive characteristics of types of time pressure

\begin{tabular}{|c|c|c|c|}
\hline Time pressure & Situational (STP) & Chronic (CTP) & Ultimate (UTP) \\
\hline Time limit & $\begin{array}{l}\text { Yes: Internal or } \\
\text { external }\end{array}$ & $\underline{\text { No }}$ & Yes: death \\
\hline Duration & $\begin{array}{l}\text { Short: Until the date } \\
\text { of the time limit }\end{array}$ & $\begin{array}{l}\text { Long: Continually } \\
\text { restarts every day }\end{array}$ & $\begin{array}{l}\text { Unknown - tends to be } \\
\text { long: Until } \\
\text { the individual's death }\end{array}$ \\
\hline $\begin{array}{l}\text { Individuals } \\
\text { concerned }\end{array}$ & $\begin{array}{l}\text { Individuals subject } \\
\text { to a time limit } \\
\text { (internal or external) } \\
\text { relating to a specific } \\
\text { task } \\
\text { (a job, a purchase, a } \\
\text { project to complete) }\end{array}$ & $\begin{array}{l}\text { Individuals } \\
\text { constantly in a } \\
\text { rush. } \\
\text { Tends to be } \\
\text { widespread in } \\
\text { Western } \\
\text { populations }\end{array}$ & $\begin{array}{l}\text { Individuals that are } \\
\text { conscious of the approach } \\
\text { of death, } \\
\text { this generally follows an } \\
\text { event, such as entering } \\
\text { retirement, that causes } \\
\text { them to realise they are } \\
\text { ageing }\end{array}$ \\
\hline $\begin{array}{l}\text { Time period } \\
\text { concerned }\end{array}$ & $\begin{array}{l}\text { The amount of time } \\
\text { left before the time } \\
\text { limit }\end{array}$ & $\begin{array}{l}\text { The amount of time } \\
\text { in a day } \\
\text { (without a time } \\
\text { limit) }\end{array}$ & $\begin{array}{l}\text { The amount of time left } \\
\text { before dying }\end{array}$ \\
\hline $\begin{array}{l}\text { Type of affective } \\
\text { reaction }{ }^{2}\end{array}$ & $\begin{array}{l}\text { Emotion, or even } \\
\text { judgement }\end{array}$ & Feeling & Feeling \\
\hline
\end{tabular}

\footnotetext{
${ }^{2}$ Affective reactions can be positive or negative regardless of the type of time pressure. The expression 'affective reactions' refers to a generic category, covering emotions, feelings and moods (Derbaix and Poncin, 2005). Lichtlé and Plichon (2014) list certain characteristics of emotions: they are generally provoked by an external stimulus (e.g., the atmosphere of a point of sale) and are short-term. Thus, the term 'emotion' seems appropriate to describe the affective aspect of situational time pressure, which is short-term and generally linked to an external event. In contrast, a 'feeling' lasts longer (Derbaix and Pham, 1989) and is more strongly associated with cognitive mechanisms. Therefore, due to the long-term nature of UTP, the associated affective reaction cannot be an emotion. The term 'feeling' thus seems more appropriate, owing to its intellectualised nature and its duration.
} 
Table 2 - Results of exploratory and confirmatory factorial analysis.

\begin{tabular}{|l|l|l|l|}
\hline \multicolumn{4}{|c|}{ PCA summary, sample no. 2 (180 individuals) } \\
\hline & $\begin{array}{c}\text { Dimension 1 (negative } \\
\text { affective dim.) }\end{array}$ & $\begin{array}{c}\text { Dimension 2 } \\
\text { (cognitive dim.) }\end{array}$ & $\begin{array}{c}\text { Dimension 3 } \\
\text { (positive affective } \\
\text { dim.) }\end{array}$ \\
\hline Eigenvalue & 4.1 & 1.6 & 1.2 \\
\hline \% explained variance & $37 \%$ & $15 \%$ & $11.3 \%$ \\
\hline Cronbach's $\boldsymbol{\alpha}$ & 0.772 & 0.784 & 0.771 \\
\hline Number of items & 4 & 4 & 3 \\
\hline \multicolumn{2}{|c|}{ CFA summary, sample no. 3 (333 individuals) } \\
\hline \\
\hline
\end{tabular}

${ }^{3}$ The solid statistics with maximum likelihood estimate (MLE) produce fit indices corrected on the basis of the level of deviation from multivariate normality when the Mardia G2P Normalized estimate coefficient is higher than 3 (here 5.5 and 8). 
Table 3 - UTP scale reliability and validity

\begin{tabular}{|c|c|c|c|c|c|c|}
\hline & \multicolumn{4}{|c|}{ Reliability } & \multicolumn{2}{|c|}{$\begin{array}{c}\text { Convergent } \\
\text { validity }\end{array}$} \\
\hline Dimension & \multicolumn{2}{|c|}{$\alpha$} & \multicolumn{2}{|c|}{$\rho$} & $\mathrm{Z}$ test & Pvc \\
\hline Cognitive & \multicolumn{2}{|c|}{0.83} & \multicolumn{2}{|c|}{0.83} & $>11$ & 0.56 \\
\hline Positive affective & \multicolumn{2}{|c|}{0.81} & \multicolumn{2}{|c|}{0.81} & $>13$ & 0.58 \\
\hline Negative affective & \multicolumn{2}{|c|}{0.76} & \multicolumn{2}{|c|}{0.76} & $>9$ & 0.46 \\
\hline Advised value (Hair et al., 2010) & \multicolumn{2}{|c|}{$>0.7$} & \multicolumn{2}{|c|}{$>0.7$} & $>1.96$ & $>0.5$ \\
\hline \multicolumn{7}{|c|}{ Discriminant validity } \\
\hline & $\begin{array}{c}\text { CTP } \\
\text { (cognitive } \\
\text { dim.) }\end{array}$ & $\begin{array}{c}\text { Cognitive } \\
\text { UTP }\end{array}$ & $\begin{array}{c}\text { Positive } \\
\text { affective } \\
\text { UTP }\end{array}$ & $\begin{array}{c}\text { Negative } \\
\text { affective } \\
\text { UTP }\end{array}$ & $\begin{array}{c}\text { Death } \\
\text { anxiety }\end{array}$ & $\begin{array}{c}\text { Second } \\
\text { order } \\
\text { UTP }\end{array}$ \\
\hline CTP (cognitive dim.) & 0.70 & & & & & \\
\hline Cognitive UTP & 0.28 & 0.75 & & & & \\
\hline Positive affective UTP & 0.23 & 0.40 & 0.76 & & & \\
\hline Negative affective UTP & 0.45 & 0.41 & 0.52 & 0.68 & & \\
\hline Death anxiety & 0.24 & 0.33 & 0.38 & 0.59 & 0.80 & \\
\hline Second order UTP & 0.49 & & & & 0.65 & 0.68 \\
\hline
\end{tabular}


Figure 1: Influence of UTP on retirees' motivations to volunteer

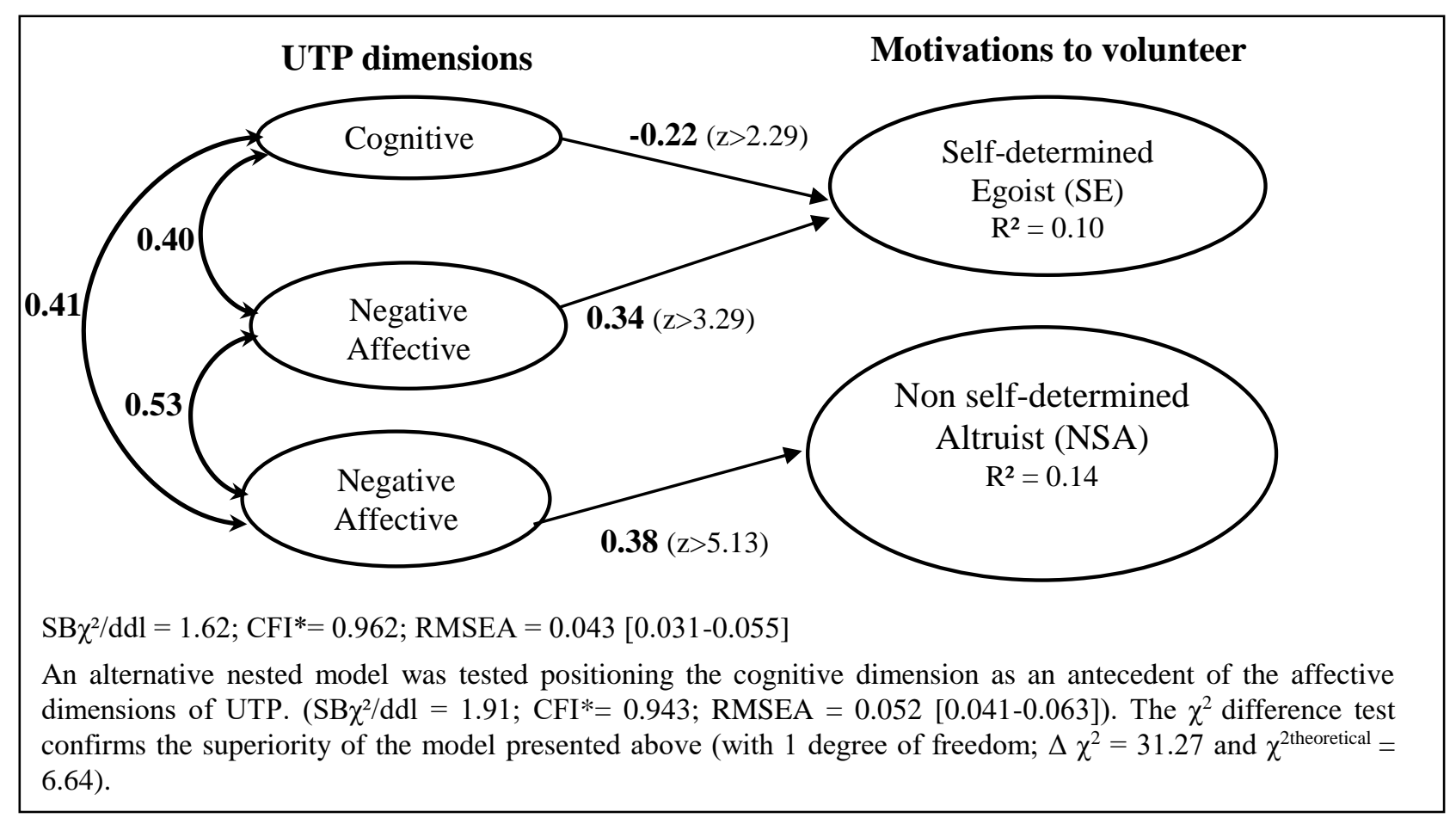




\section{BIBLIOGRAPHY}

Adjaye JK (2002) Modes of knowing: intellectual and social dimensions of time in Africa. Kronoscope 2(2): 199-224.

Agostinho D et Paço A (2012) Analysis of the motivations, generativity and demographics of the food bank volunteer. International Journal of Nonprofit and Voluntary Sector Marketing 17(3): 249-261.

Allard-Poesi F (2003) Coder les données. In: Giordano Y (ed) Conduire un projet de recherche : une perspective qualitative. Colombelles: EMS Management \& société, pp. 245-290.

Attias-Donfut C (2006) Temps social, temps individuel et vieillissement. In: Attias-Donfut C, Cyrulnik B, Klein E et Misrahi R (eds) Penser le temps pour lire la vieillesse. Paris: Presses Universitaires de France.

Balbo G (1989) D'un vieillissement outre âge. In: Bianchi H (ed) La question du vieillissement : perspectives psychanalytiques. Paris: Dunod, pp.74-106.

Bazeley P (2007) Going further. In: Bazeley P (ed) Qualitative data analysis with NVivo. London: Sage Publications, pp.177-209.

Bergadaà M (1988) Le temps et le comportement de l'individu (Part 1). Recherche et Applications en Marketing 3(4): 57-72.

Bergadaà M (1989) Le temps et le comportement de l'individu (Part 2). Recherche et Applications en Marketing 4(1): 37-55.

Bergadaà M (1990) The role of time in the action of the consumer. Journal of Consumer Research 17(3): 289-302.

Bergadaà M et Urien B (2008) La personne âgée : son attitude face à l'idée de mort, le cadre temporel de son action et son sens de l'objet. In: Actes de la conférence Rupture, finitude, mort et Management, Brest, France, 25-26 juin 2008.

Bianchi H (1987) Le Moi et le temps : psychanalyse du temps et du vieillissement. Paris: Bordas.

Bianchi H (1989) Vieillir, ou les destins de l'attachement. In: Bianchi H (ed) La question du vieillissement : perspectives psychanalytiques. Paris: Dunod, pp.33-63.

Bidee J, Vantilborgh T, Pepermans R, Huybrechts G, Willems J, Jegers M et Hofmans J (2013) Autonomous motivation stimulates volunteers' work effort: A self-determination 
theory approach to volunteerism. VOLUNTAS: International Journal of Voluntary and Nonprofit Organizations 24(1): 32-47.

Boulbry G, Jacob C et Guéguen N (2012) Effets des formats publicitaires classiques de l'internet sur les réactions cognitives, affectives et conatives de deux segments d'âges opposés. In: Actes du $28^{\text {ème }}$ congrès de l'Association Française du marketing, Brest, France, 9-11 mai 2012.

Bourcier-Béquaert B et De Barnier V (2011) Les émotions chez les personnes âgées : entre pression temporelle et effet d'expérience. In: Actes des $10^{\text {èmes }}$ Journées Normandes de la Recherche sur la Consommation, Rouen, France, 18 mars 2011.

Bourcier-Béquaert B et De Barnier V (2012) Le sens donné par les personnes âgées à leurs consommations. In: Guiot D et Urien B (ed) Comprendre le consommateur âgé : Nouveaux enjeux et perspectives. Bruxelles: De Boeck, pp.107-128.

Caradec V (2008) Les «personnes âgées », un groupe d'âge hétérogène. In: Caradec V (ed) Sociologie de la vieillesse et du vieillissement. Paris: A. Colin, pp.42-86.

Carstensen LL (1991) Selectivity theory: social activity in life-span context. In: Schaie KW et Lawton MP (ed) Annual review of gerontology and geriatrics 11, pp.195-217.

Carstensen LL (1992) Social and emotional patterns in adulthood: support for socioemotional selectivity theory. Psychology and Aging 7(3): 331-338.

Carstensen LL et Lang FR (1996) Future time perspective scale. Unpublished manuscript. Stanford University.

Centre d'études et de recherches sur la philantropie - Cerphi (2010) Les associations et les seniors bénévoles : nouvelles relations et nouvelles pratiques. Disponible sur : http://www.cerphi.org/etudes-et-recherches-disponibles/le-benevolat-les-benevoles/ (accédé le 08 janvier 2016).

Centre d'études et de recherches sur la philantropie - (2012), L'engagement bénévole des seniors - de 50 à 65 ans en France. Disponible sur: http://www.aveengagements.fr/IMG/pdf/Sondage_Engagement_des_seniors-2.pdf (accédé le 08 janvier 2016).

Chantal Y et Vallerand RJ (2000) Construction et validation de l'échelle de motivation envers l'action bénévole (EMAB). Society and Leisure 23: 477-508.

Chevalier C, Le Serre D et Lichtlé MC (2013) La recherche d'information des seniors : caractéristiques et typologie. In: Actes du $29^{\text {ème }}$ congrès de l'Association Française du Marketing, La Rochelle, France, 14-15 mai 2013. 
Churchill GA (1979) A paradigm for developing better measures of marketing constructs. Journal of marketing research 16(1): 64-73.

Clary EG, Snyder M et Stukas AA (1996) Volunteers' motivations: findings from a national survey. Nonprofit and Voluntary Sector Quarterly 25(4): 485-505.

Clément S (2007) Le discours sur la mort à l'âge de la vieillesse. Retraite et Société, 3(52): 63-81.

Dávila MC et Díaz-Morales JF (2009) Age and motives for volunteering: Further evidence. Europe's Journal of Psychology (2): 82-95.

De Hennezel M (2010) Vieillir. In: De Hennezel M et Vergely B (ed), Une vie pour se mettre au monde. Paris: Carnets nord, pp.11-62.

Delacroix E et Jourdan P (2007) La tendance à regretter du consommateur : validation d'une échelle de mesure. Recherche et Applications en Marketing 22(1): 25-44.

Derbaix C et Pham MT (1989) Pour un développement des mesures de l'affectif en marketing : synthèse des prérequis. Recherche et Applications en Marketing 4(4): 71-87.

Derbaix C et Poncin I (2005) La mesure des réactions affectives en marketing, évaluation des principaux outils. Recherche et Applications en Marketing. 20(2): 55-75.

Erikson E (1959) Identity and the life cycle: Selected papers. Psychological Issues 1: 50-100.

Erlinghagen M et Hank K (2005) Participation of older europeans in volunteer work. Papier de recherche, Mannheim research institute for the economics of aging (MEA), 71: pp.1-27. Disponible sur : http://econpapers.repec.org/paper/meameawpa/05071.htm (accédé le 08 janvier 2016).

Erlinghagen M (2010) Volunteering after retirement. Evidence from German panel data. European Societies, 12(5): 603-625.

Finkelstein MA (2009) Intrinsic vs. extrinsic motivational orientations and the volunteer process. Personality and Individual Differences 46(5-6): 653-658.

Fontaine R (2007) Psychologie du vieillissement. $2^{\mathrm{e}}$ édition. Paris: Dunod.

Fromage B (2007) Approche du vieillissement à travers l'expérience subjective. L'information psychiatrique 83(3): 229-233.

Gagey J (1989) Raisonner psychanalytiquement le vieillir? In Bianchi H (ed) La question du vieillissement : perspectives psychanalytiques. Paris: Dunod, pp.7-32.

Gagné M, Forest J, Vansteenkiste M, Crevier-Braud L, Van den Broeck A, Aspeli A, Bellerose J, Bénabou C, Chemolli E, Güntert ST, Halvari H, Johnson P, Indiyastuti DL, Molstad M, Naudin M, Ndao A, Roussel P, Westbye C et Wang Z (2015) The 
multidimensional work motivation scale: Validation evidence in seven languages and nine countries. European Journal of Work and Organizational Psychology 24(2): 178-196.

Gourmelen A et Guillemot S (2012) Pourquoi donner son temps lorsque celui-ci est compté ? L'influence de la générativité sur les motivations des bénévoles retraités. In: Actes du $28^{\text {ème }}$ congrès de l'Association Française du Marketing, Brest, France, 9-11 mai 2012.

Guiot D (2006) Un cadre d'analyse du processus de vieillissement et de son influence sur le comportement d'achat du consommateur âgé. Recherche et Applications en Marketing 21(1): $57-79$.

Hair JF, Black WC, Babin BJ et Anderson RE (2010) Multivariate data Analysis (7 ${ }^{\text {ème }}$ édition). Prentice Hall.

Haivas S, Hofmans J et Pepermans R (2012) Self-determination theory as a framework for exploring the impact of the organizational context on volunteer motivation: A study of romanian volunteers. Nonprofit and Voluntary Sector Quarterly 41(6): 1195-1214.

Haski-Leventhal D (2009) Elderly volunteering and well-being: a cross-European comparison based on SHARE data. VOLUNTAS: International Journal of Voluntary and Nonprofit Organizations 20(4): 388-404.

Huberman AM et Miles MB (1991) Analyse pendant le recueil des données. In: Huberma AM et Miles MB (ed) Analyse des données qualitatives - Recueil de nouvelles méthodes. Bruxelles: De Boeck, pp.88-138.

Huteau M (2006) Psychologie différentielle : cours et exercices. $3^{\mathrm{e}}$ édition. Paris: Dunod.

Ionescu S, Jacquet MM et Lhote C (2012) Les mécanismes de défense : théorie et clinique. 2e édition Paris: A. Colin.

Jolibert A et Jourdan P (2011a) Les techniques d'analyse qualitatives. In Jolibert A et Jourdan P (ed) Marketing research, méthodes de recherche et d'études en marketing. Paris: Dunod, pp.49-65.

Jolibert A et Jourdan P (2011b) La construction d'une échelle de mesure. In Jolibert A et Jourdan P (ed) Marketing research, méthodes de recherche et d'études en marketing. Paris: Dunod, pp.178-198.

Lalive d'Epinay C et Cavalli S (2007) Changements et tournants dans la seconde moitié de la vie. Gérontologie et Société 2(121): 45-60.

Lallement J (2008) Les effets de la pression temporelle sur le traitement des informations et le comportement d'achat. Thèse de doctorat, Université de Tours, France. 
Lallement J (2010) L'impact de la pression temporelle sur le traitement des informations. Recherche et Applications en Marketing 25(4): 45-68.

Lallement J et Machat S (2011) «Au secours, tout va trop vite ! » Nécessité d'une

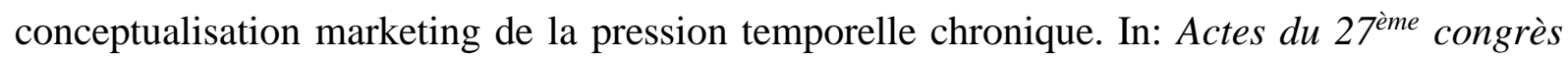
de l'Association Française du Marketing, Bruxelles, Belgique, 19-20 mai 2011.

Lichtlé MC et Plichon V (2014) Les émotions ressenties dans un point de vente : Proposition d'une échelle de mesure. Recherche et Applications en Marketing 29(1): 3-26.

Machat S et Lallement J (2011) Vite fait, bien fait ? Proposition de mesure de la pression

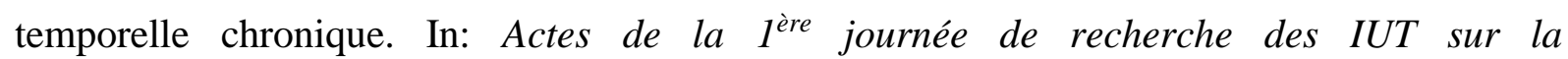
commercialisation, Saint-Denis, France, 3 mars 2011.

Malas Z (2009) Le rapport à l'avenir, déterminant des choix patrimoniaux des personnes âgées. Thèse de doctorat, Université de Paris Dauphine, Paris, France.

Malas Z et Guiot D (2008) L'étude du rapport à l'avenir en marketing chez les plus de 50 ans : différences conceptuelles et mesures alternatives. In: Actes du $24^{\text {ème }}$ congrès de l'Association Française du Marketing, Paris, France, 15-16 mai 2008.

Malas Z et Safraou I (2008) La mesure de l'horizon temporel par Carstensen et Lang : discussion, traduction et validation de l'échelle sur une population française de plus de 50 ans. In: Actes de la conférence Rupture, finitude, mort et Management, Brest, France, 25-26 juin 2008.

Marbot E et Peretti JM (2004) Les seniors dans l'entreprise. Paris: Village Mondial, Pearson Education France.

Marchand I, Quéniart A et Charpentier M (2010) Vieillesses d'aujourd'hui : les femmes aînées et leurs rapports aux temps. Enfances, Familles, Générations 13: 59-78.

McAdams DP, de St Aubin E et Logan RL (1993) Generativity among young, midlife, and older adults. Psychology and aging 8: 221-230.

Miles MB et Huberman AM (2003) Donner un sens : élaboration et vérification des conclusions. In Miles MB et Huberman AM (ed) Analyse des données qualitatives. Bruxelles: De Boeck, pp.437-518.

Misrahi R (2006) Conversion et temps vécu : vieillesse, gérontologie, philosophie. In AttiasDonfut C, Cyrulnik B, Klein E et Misrahi R (ed) Penser le temps pour lire la vieillesse. Paris : Presses Universitaires de France.

Morrow-Howell N (2010) Volunteering in later life: research frontiers. The Journals of Gerontology, Series B, Psychological Sciences and Social Sciences 65(4): 461-469. 
Moschis GP et Nickell D (2012) Comprendre les motivations d'entrée dans un établissement d'hébergement médicalisé : le cas des Etats-Unis. In Guiot D et Urien B (ed) Comprendre le consommateur âgé : nouveaux enjeux et perspectives. Bruxelles: De Boeck, pp.179-194.

Mutchler JE, Burr JA et Caro FG (2003) From paid worker to volunteer: leaving the paid workforce and volunteering in later life. Social Forces 81(4): 1267-1293.

O’Neill G, Morrow-Howell N et Wilson SF (2011) Volunteering in later life: from disengagement to civic engagement. In: Settersten RA Jr et Angel JL (ed) Handbook of Sociology of Aging. Springer, pp.333-350.

Okun MA et Schultz A (2003) Age and motives for volunteering: testing hypotheses derived from socioemotional selectivity theory. Psychology and aging 18(2): 231-239.

Okun MA, Barr A et Herzog AR (1998) Motivation to volunteer by older adults: a test of competing measurement models. Psychology and Aging 13(4): 608-621.

Paillé P et Mucchielli A (2008) L'examen phénoménologique des données empiriques. In: Paillé P et Mucchielli A (ed) L'analyse qualitative en sciences humaines et sociales. Paris: Armand Colin, pp.85-98.

Point S et Voynnet-Fourboul C (2006) Le codage à visée théorique. Recherche et Applications en Marketing 21(4): 61-78.

Prouteau L et Wolff FC (2004) Donner son temps: les bénévoles dans la vie associative. Economie \& Statistique 372: 3-39.

Prouteau L et Wolff FC (2007) La participation associative et le bénévolat des seniors. Retraite et Société 1(50): 157-189.

Pyszczynski T, Greenberg J et Solomon S (1999) A dual-process model of defense against conscious and unconscious death-related thoughts: an extension of terror management theory. Psychological Review 106(4): 835-845.

Reed AE et Carstensen LL (2012) The theory behind the age-related positivity effect. Frontiers in psychology 3: 1-9.

Rizkalla AN (1989) Sense of time urgency and consumer well-being: testing alternative causal models. In: Advances in Consumer Research, 16, pp.180-188.

Rosa H (2010) Accélération et croissance : les forces motrices externes de l'accélération sociale. In Rosa H (ed) Accélération : une critique sociale du temps. Paris: La Découverte, pp.199-239.

Rossiter JR (2002) The C-OAR-SE procedure for scale development in marketing. International Journal of Research in Marketing 19(4): 305-335. 
Rossiter JR (2011) Marketing measurement revolution: the C-OAR-SE method and why it must replace psychometrics. European Journal of Marketing 45: 1589-1600.

Roussel P, Durrieu F, Campoy E et El Akremi A (2002) Méthodes d'équations structurelles : recherche et applications en gestion. Paris: Economica.

Schau HJ, Gilly MC et Wolfinbarger M (2009) Consumer identity renaissance: The resurgence of identity-inspired consumption in retirement. Journal of Consumer Research 36(2): 255-276.

Schwartz B, Ward A, Monterosso J, Lyubomirsky S, White K et Lehman DR (2002) Maximizing versus satisficing: happiness is a matter of choice. Journal of Personality and Social Psychology 83(5): 1178-1197.

Szmigin I et Carrigan M (2001) Time, consumption, and the older consumer: an interpretive study of the cognitively young. Psychology and Marketing 18(10): 1091-1116.

Szollos A (2009) Toward a psychology of chronic time pressure. Time \& Society 18(2-3): 332-350.

Talpin JM (2013) Psychologie clinique du vieillissement normal et pathologique. Paris: A. Colin.

Tang F, Morrow-Howell N et Hong S (2009) Inclusion of diverse older populations in volunteering. Nonprofit and Voluntary Sector Quarterly 38(5): 810-827.

Thomas LV (1989) Attitudes collectives envers les vieillards : un problème de civilisation. In H. Bianchi (ed) La question du vieillissement : perspectives psychanalytiques. Paris: Dunod, pp.125-160.

Tolstoï L (1986), Je m’en vais - lettre 602 à la comtesse S.A. Tolstaïa. In: Christian RF (ed) Lettres II, Gallimard, pp.385-386.

Urien B (2002) L'anxiété face à la mort : approfondissement conceptuel et étude de son influence sur la recherche de variété alimentaire. In: Actes du $18^{\text {ème }}$ congrès de l'Association Française du Marketing, Lille, France, 22-23 mai 2010.

Urien B (2003) L'anxiété face à la mort et son influence sur le comportement du consommateur. Recherche et Applications en Marketing 18(4): 23-41.

Urien B (2007) Selfless time, from life space to death anticipation. Time \& Society 16 (2-3): 367-386.

Usunier JC et Valette-Florence P (2007) The time styles scale. A review of developments and replications over 15 years. Time \& Society 16(2-3): 333-366. 
Van Hiel A, Mervielde I, et De Fruyt F (2006) Stagnation and Generativity: structure, validity, and differential relationships with adaptive and maladaptive personality. Journal of Personality 74(2): 543-574.

Van Ingen E et Dekker P (2011) Changes in the determinants of volunteering: participation and time investment between 1975 and 2005 in the Netherlands. Nonprofit and Voluntary Sector Quarterly 40(4): 682-702.

Vergely B (2010) Mûrir. In: De Hennezel M et Vergely B (ed) Une vie pour se mettre au monde. Paris: Carnets nord, pp.63-118.

Wang PZ (2004) Assessing motivations for sports volunteerism. In: Advances in Consumer Research, 31, pp.420-425.

Warburton J et Crosier T (2001) Are we too busy to volunteer? The relationship between time and volunteering using the 1997 ABS time use data. Australian Journal of Social Issues 36(4): 295-314.

Wiedmer JP (2010) Les seniors, des passeurs de vie. In Wiedmer JP (ed) Enfin senior!, Paris: Nouveaux débats publics, pp.189-209.

Zedlewski SR et Schaner SG (2006) Older adults engaged as volunteers. Perspectives On Productive Aging 5: 1-7.

Zeelenberg M (1999) The use of crying over spilled milk: a note on the rationality and functionality of regret. Philosophical Psychology 12(3): 325-340. 